\title{
Constructivism Approaches in Teaching and Learning Computer Programming
}

\author{
Mohd Faizul Emizal Bin Mohd Ghazia ${ }^{\mathrm{a}}$ Astri Idayu Binti Athesan ${ }^{\mathrm{b} *}$

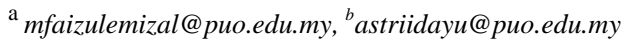 \\ Lecturer, Department of Information and Communication Technology, \\ Polytechnic Ungku Omar, Malaysia
}

\begin{abstract}
This paper discusses the application of constructivist approaches for teaching and learning computer programming in Problem Solving and Program Design courses. It provides an overview of constructivist approaches and how to adapt to current teaching technique. The paper then describes how educators must change their role from being a source of direct transfer to being a reference source that guides and triggers students' interest and understanding. The approach accentuates the need of active and collaborative learning for them to discover and be able to construct new knowledge. This approach focuses on enGauge 21st Century Skills education model which are mapped to the suitable Constructivist Teaching Modes to teach programming in the classroom teaching module. Module developed are used as tools in delivering, to facilitate the idea of programming concepts approach. The context is based on constructivism teaching where the educators act as a facilitator during class to accommodate the unique learning curve of each individual. The technology allows guided exploration yet indulges in a dynamic learning process that can spark the formation of self-directed learning patterns which suits individuals as well as combinations of groups of students. To achieve this, educators need to devise an appropriate approach in their teaching pattern towards the effective learning delivery for constructivist teaching of computer science and technology.
\end{abstract}

“Keywords: Constructivism, Programming, Self-directed learning, Teaching pattern”

\section{Introduction}

The $21^{\text {st }}$ century learning was introduced by the Ministry of Education (MOE) Malaysia, with aims to improve the quality of the education system through the success of students' formation who can master the knowledge, skills, and values that should provide them to be able to contend globally. In accord with the needs in the industry that requires knowledgeable and skilled human capital, North Central Regional Educational Laboratory (NCREL) and Metiri Group have introduced a 21st century education model known as enGauge 21 st Century Skills. This model emphasizes on the importance of learning engagement through authentic, realworld experiences (The North Central Regional Educational Laboratory, 2003). The engagement interprets new standards and determines how to include principles of learning towards student-centred approach.

P21 Framework is one of the example models that emphasize on incorporating 21 st century skills into learning as shown in Figure 1 (Partnership for 21st Century learning, 2015). This model witnessed a more dynamic and creative display of teaching and learning process with relevant teaching content according to current developments. Based on Learning and Innovation Skills component in P21 Framework, we develop a teaching module focus on the promoting the 4C's -Creativity, Critical Thinking, Communication, and 
Collaboration. Guo \& Woulfin, 2016 supported the effectiveness of this idea through an investigation which concluded the importance of educators to form learning materials that assist in the nurture of the 4C's through the P21 Framework.

Thus, administrators, educators, and students have their own role in empowering the 21 st century-based education model. As an example, administrators should determine effective technology resources and support the identified approach by educators to include principles of creativity into the structures and practices of learning. Students then should commit to the applied lesson through exploration to develop the skills needed. Some of the skills utilize are ICT literacy, inventive thinking, communication skills and productivity outcomes. These shows the components interrelation to encourage a form of constructivism learning.

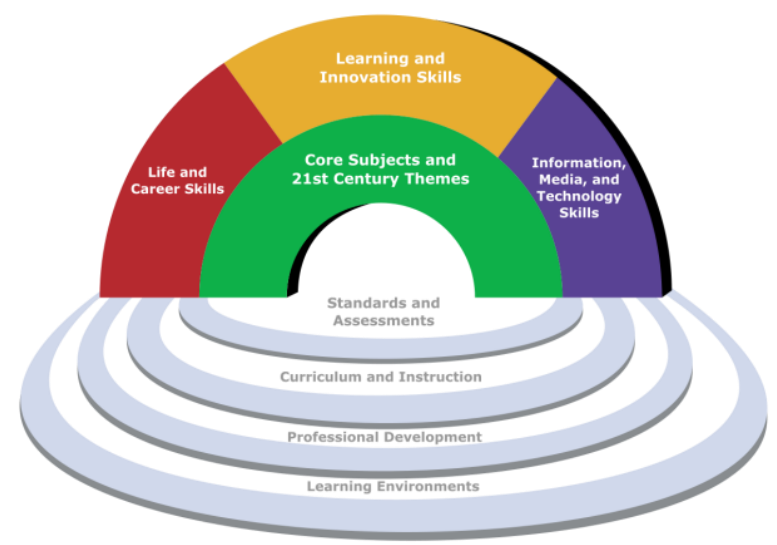

Fig. 1. P21 Framework for $21^{\text {st }}$ Century Learning

Innovative Teaching Practice (ITP) is one of the system renewals method suggest by Langworthy, 2013 that focuses on a combination of Student-Centred Pedagogies, Extending Learning, and ICT Integration as referred to Table 1. To ensure the effectiveness, the teaching module are structure to personalized in Knowledge construction and Collaborative under the components of Student-Centred Pedagogies. Whereas in reaching the learning process for long-term access point, problem solving methods are the one we choose for components of Extending Learning. For components of ICT Integration, the module use consists of knowledge building and creativity by both educators and students.

Table 1. Innovative Teaching Practices (ITP)

\begin{tabular}{lll}
\hline Student-Centred Pedagogies & Extending Learning & ICT Integration \\
\hline Knowledge construction & Problem solving & By educators \\
\hline Personalized & 24/7 learning opportunities & By students \\
\hline Collaborative & Global and cultural understanding & $\begin{array}{l}\text { Basic usage vs. Higher-level usage } \\
\text { (for knowledge building and } \\
\text { creativity) }\end{array}$ \\
\hline Self-regulation & & -
\end{tabular}




\section{Problem Statement}

The evolution of technology foreseen the needs of a learning system which was already based on formalised teaching but with the assistance of technology resources in education. The importance of technology are supported by Guo \& Woulfin, 2016 study with a view indicating technology as important role in providing resources for implementing teaching creativity.

The native teaching and learning process are no longer suitable and new approaches are needed to transform the teaching and learning process into an effective process especially in teaching programming. Although the in-class repetitive exercise aims to generate the skills on implementing knowledge owned, thus the student's achievement can be supported and improved through the constructivism-based learning. Students can revise their own knowledge, understand new information, evaluate mastery level, and attempt self-reflect to stimulate their mind, and strengthen their skills through exploration. Therefore, a teaching module is developed to help educators manage a few issues arising in teaching Problem Solving and Program Design courses. The teaching module aims to accommodate the issues using robotic tools as an intermediate through appropriate teaching approach. Factors that need to be addressed are as follows:

- The systematic, effective, and active transfer of knowledge mode.

- For educators to become a source of reference during learning activities.

- The suitable method and acquisition process can be assisted and enhanced in class.

- To be able to supplement the less-interested students' need in learning programming.

- The groundwork of teaching and learning approaches in accordance with the course content.

\section{Constructivism Teaching and Learning}

\subsection{Constructivism Learning}

Study by Sang, 2010 interprets learning as an internal process faced by students through their experience, knowledge and skills provided and causes permanent impact to the cognitive and behavioural changes in students. This supports the ideas of learning to be the description of principles and laws that are intertwined and interdependent in the mastery of knowledge and information.

There are four epistemological assumptions to be the core on related Constructivist Learning based on study by Sugrah, 2020. First, knowledge will be physically built by the students during their involvement in active learning. Second, knowledge is constructed symbolically by students when they able to make descriptions from their own actions. Third and fourth assumptions involve knowledge where it is built generally when they meant something to individual and theoretically construct from their understanding to explain something.

According to Elliott et al., 2000, constructivism is 'an approach to learning that holds people actively to make or construct their knowledge which is determined by learner own experiences'. This means the previous knowledge influences the interpretation of new or modified knowledge exposed to an individual which then can be constructed to form new learning experiences.

The principles of constructivism saying human learning is constructed from new knowledge that are gained upon the foundation of previous learning indicates the demand in active learning patterns. Learners are no longer in a passive mode state waiting to be fed up but need to actively participate to gain knowledge. The engagement forms a socially constructed environment that produces unique outcomes for each learner.

Table 2 shows the summary of elements in constructivism principle considered to affect during constructivism learning (McLeod, n.d.) his form of engagement is usually found in experimental or problembased solving. 
Table 2. Elements in Constructivism Principle

\begin{tabular}{ll}
\hline Elements & Description \\
\hline Knowledge Development & $\begin{array}{l}\text { It holds the idea of knowledge is constructed, rather than naturally appeared, or } \\
\text { passively absorbed. }\end{array}$ \\
\hline Active Learning & $\begin{array}{l}\text { Information may be received in a passive form but for learners to convert the } \\
\text { information to context correct understanding are built from meaningful } \\
\text { connections between prior knowledge, new knowledge, and the processes } \\
\text { involved in learning. }\end{array}$ \\
\hline Socially Constructed & $\begin{array}{l}\text { The environment in which learners are exposed will influence the one's way of } \\
\text { thinking and form of thinking }\end{array}$ \\
\hline Knowledge is Personal & $\begin{array}{l}\text { Each learner may result in different learning outcomes for the same lesson as } \\
\text { their subjective interpretations differ based on their previous experience of } \\
\text { existing knowledge and values. }\end{array}$ \\
\hline
\end{tabular}

The concept holds on the ideas of students not to rely on someone else's information and only accepting. Instead, the students are exposed to data, primary sources, and the ability to interact with other students throughout the learning process and then incorporate their experiences. The module, lesson plans, and study skills created through activity able to host different backgrounds and the learning experience. Educators then supervise and flexibly guide the learning environment accommodating the diversity between students to be formed together through information analysing and ideas generated.

\subsection{Constructivism Teaching}

As explained, constructivism is based on students-centred rather than curriculum based. These concepts evolve in the context of knowledge construction rather than knowledge reproduction where educators act most of their roles as facilitators. It stresses on the real situations and social communicative activities throughout collaborations using multidisciplinary sources in obtaining solutions. All the thoughts stated are supported in the research of Liu \& Zhang, 2014 based on the four main constructivist teaching views theory.

As the modules developed are prearranged to be an open-ended question, students are indirectly forced into a student-centred autonomous learning environment. They need to solve the given task through their prior knowledge and experience learned on basic subjects (mathematics, science, language, arts, etc) to correlate with current situation during problem solving and assimilate new information. There are four most influential teaching modes identified as Random-Access Instruction, Scaffolding Instruction, Situated or Anchored Instruction and Top-down Instruction as described in Table 3 (Liu \& Zhang, 2014).

Table 3. Constructivist Teaching Modes

\begin{tabular}{lll}
\hline Index & Modes & Description \\
\hline A & Random-Access Instruction & $\begin{array}{l}\text { Students can access to the learning objects from various methods and } \\
\text { exploration to gain the insight and understanding of the issue need to be } \\
\text { solve from different aspects }\end{array}$ \\
\hline B & Scaffolding Instruction & $\begin{array}{l}\text { Illustrate teaching mode consists of two states of assistance during } \\
\text { students Zone of Proximal Development (ZPD) which are (1) educator } \\
\text { role as facilitator and (2) competent team members through } \\
\text { collaboration. The support is reduced with the progress of students able } \\
\text { to engage in their cognitive activities at higher levels. }\end{array}$ \\
\hline C & Situated or Anchored Instruction & $\begin{array}{l}\text { Exemplify with related facts and examples to lead students to bridge the } \\
\text { connection between experience in real situations with the problem to be } \\
\text { solved. }\end{array}$ \\
\hline D & Top-down Instruction & $\begin{array}{l}\text { Educator guides in the form of instruction for the activity to which } \\
\text { students verify the knowledge received through application, building } \\
\text { understanding through conversation, and clarifying confusion along the } \\
\text { way. }\end{array}$ \\
\hline
\end{tabular}




\section{Constructivism in Teaching Programming}

In this study we discuss the teaching module design to focusses on the delivered method structure. It acts as a transitional tool to help educators deliver and adapt the teaching and learning process planned in form of constructive context. Mayer, 2004 stated that study by educational psychology suggested that teaching and learning are based on subject-specific activities. To suit this idea, a well-planned teaching plans, using the correct approach and tools are thought to assist in teaching programming.

The module accentuates on the existing knowledge that they have learn previously during their secondary and higher education. Students then embed their new form of techniques learn as logic programming which will then help them to create solution. The module produces are outlined to be in form of problem-based learning through an already familiarize real-life activity. The process produced a meaningful construction of knowledge as they either reapplied what they have learn or recreate new form of knowledge understanding.

According to Brown \& Wilson, 2018, ability to code a computer program does not come naturally but a learning skill refined and acquired through practices. Educators may well use this fact to relate each lesson in a form of dynamic learning categorized by change, activity, and progress. The form of teaching chosen in the module were intentionally designed to gather students' needs while challenging them to enhance their current skills, interests, and perceptions, and to significantly build a new one.

Based on the teaching modes discussed, the suitable teaching techniques are being mapped to each subtopic build to the module lesson planned shown in Table 4. Each technique approach is planned to encourage and support the proposed enGauge $21^{\text {st }}$ century skills of Inventive Thinking and Effective Communications. Teachers' roles change from authority and knowledge transmitter into the organizer of activities and facilitator of meaning construction.

Since constructivist theory does not encourage centralized summative assessment, formative and continuous assessment are generated instead and need to be conducted simultaneously with the process of knowledge construction and mastery. In-class discussions through the hands-on activities are a form of formative assessments that is best suited to the constructivism applications encouraging critical thinking and learning.

Educators are encouraged to develop a dynamic and flexible program based on the individual's existing knowledge as well as practical problem-solving. Some of the strategies planned for the module implementation that uses the concept of constructivism include collaboration between students that cultivates them to answer one another's questions. The approach will then expand having to identify one student as the expert on the subject to help guide the learning process.

The differences of constructed learning being developed between each group members will aid to support each member's level of understanding. By encouraging this, it is beneficial to divert students' own method of learning to a wider range of solutions by thinking outside the box. Students will either interpret what they see to fit the knowledge they have encountered before or they will adapt their new knowledge to better explain this new information (Syahida Nadia Zakaria, 2015). 
Table 4. Module activity and technique/method mapping

\begin{tabular}{|c|c|c|c|c|}
\hline No. & Module Activity & Technique & Teaching Modes & EnGauge Skills \\
\hline 1. & $\begin{array}{l}\text { (a) Activity 1: Hello } \\
\text { Sphero }\end{array}$ & $\begin{array}{l}\text { Teacher-Centered Instruction } \\
\text { Direct Instruction }\end{array}$ & $\mathrm{A}, \mathrm{D}$ & $\begin{array}{l}\text { Curiosity, } \text { Creativity and } \\
\text { Taking }\end{array}$ \\
\hline \multirow[t]{2}{*}{2.} & (a) Activity 2: Geometry & $\begin{array}{l}\text { Teacher-Centered Instruction } \\
\text { Direct Instruction } \\
\text { Kinesthetics Learning }\end{array}$ & A, C, D & $\begin{array}{l}\text { Teaming, Collaboration, and } \\
\text { Interpersonal Skills }\end{array}$ \\
\hline & (b) Sphero Challenge \#2 & $\begin{array}{l}\text { Student-Centered Instruction } \\
\text { Inquiry-Based Learning }\end{array}$ & $\mathrm{C}, \mathrm{B}$ & $\begin{array}{l}\text { Adaptability, Managing Complexity, } \\
\text { and Self-Direction }\end{array}$ \\
\hline \multirow[t]{2}{*}{3.} & (a) Activity 3: Funny Me & $\begin{array}{l}\text { Teacher-Centered Instruction } \\
\text { Direct Instruction } \\
\text { Game-based Learning }\end{array}$ & A, C, D & Higher-Order Thinking Reasoning \\
\hline & (b) Sphero Challenge \#3 & $\begin{array}{l}\text { Student-Centered Instruction } \\
\text { Inquiry-Based Learning }\end{array}$ & $\mathrm{A}, \mathrm{C}, \mathrm{D}$ & Higher-Order Thinking Reasoning \\
\hline
\end{tabular}

\section{Conclusion}

In conclusion, the theory of constructivism strongly emphasizes that learning is an active and dynamic process. Students can build new concepts and knowledge based on the experiences they have gained. Through their experience, each individual has their own representation of knowledge. Learning process occurs when students configure the imbalance of their present knowledge framework and the new information received. As students would argue with the logic of one's own mind. However, the process of forming this form of individual learning requires active participation from students. This theory is very suitable to be applied into the teaching and learning process along with the current education system which demands that every pertinent individual utilize the technological advances available today.

\section{References}

Brown, N. C. C., \& Wilson, G. (2018). Ten quick tips for teaching programming. PLoS Computational Biology. https://doi.org/10.1371/journal.pcbi.1006023

Elliott, S. N., Travers, J. F., Kratochwill, T. R., \& Littlefield Cook, J. (2000). Educational psychology: Effective teaching, effective learning. In Educational psychology: Effective teaching, effective learning.

Guo, J., \& Woulfin, S. (2016). Twenty-First Century Creativity: An Investigation of How the Partnership for 21st Century Instructional Framework Reflects the Principles of Creativity. Roeper Review, 38(3), 153-161. https://doi.org/10.1080/02783193.2016.1183741

Langworthy, M. (2013). 21 st CENTURY LEARNING DESIGN Learning that matters.

Liu, L., \& Zhang, Y. (2014). The application of constructivism to the teaching of intercultural communication. English Language Teaching, 7(5), 136-141. https://doi.org/10.5539/elt.v7n5p136

Mayer, R. E. (2004). Teaching of subject matter. Annual Review of Psychology. https://doi.org/10.1146/annurev.psych.55.082602.133124

McLeod, S. (n.d.). Constructivism as a Theory for Teaching and Learning| Simply Psychology. Retrieved February 15, 2021, from https://www.simplypsychology.org/constructivism.html

Partnership for 21st Century learning. (2015). 21st CENTURY STUDENT OUTCOMES. 1-9. http://www.p21.org/our-work/p21framework

Sang, M. S. (2010). Psikologi pendidikan dan pedagogi murid dan alam belajar / Mok Soon Sang. Penerbitan Multimedia Sdn. Bhd.,.

Sugrah, N. U. (2020). Implementasi teori belajar konstruktivisme dalam pembelajaran sains. Humanika, 19(2), $121-138$. https://doi.org/10.21831/hum.v19i2.29274

Syahida Nadia Zakaria. (2015). Kesan pendekatan konstruktivisme dan pendekatan tradisional dalam pengajaran dan pembelajaran komponen sastera Bahasa Melayu. Jurnal Pendidkan Bahasa Melayu, 5(2), 12-21. http://journalarticle.ukm.my/9857/1/93-184-1SM.pdf

The North Central Regional Educational Laboratory. (2003). enGauge 21st Century Skills: Helping Students Thrive in the Digital Age. Retrieved June, 2, 2008. http://www.ncrel.org/engauge 